\title{
Plant Secondary Metabolites-Missing Pieces in the Soil Organic Matter Puzzle of Boreal Forests
}

\author{
Bartosz Adamczyk ${ }^{1, *}$ (D), Sylwia Adamczyk ${ }^{2}$, Aino Smolander ${ }^{2}$, Veikko Kitunen ${ }^{2}$ and \\ Judy Simon $^{3}$ \\ 1 Department of Food and Environmental Sciences, University of Helsinki, PO Box 66, 00014 Helsinki, Finland \\ 2 Natural Resources Institute Finland, PL 2, 00791 Helsinki, Finland; Sylwia.Adamczyk@luke.fi (S.A.); \\ Aino.Smolander@luke.fi (A.S.); Veikko.Kitunen@luke.fi (V.K.) \\ 3 Plant Interactions Ecophysiology Group, Department of Biology, University of Konstanz, \\ Universitätsstrasse 10, 78457 Konstanz, Germany; judy.simon@uni-konstanz.de \\ * Correspondence: Bartosz.Adamczyk@helsinki.fi
}

Received: 9 December 2017; Accepted: 29 December 2017; Published: 8 January 2018

\begin{abstract}
Processes underlying soil organic matter (SOM) transformations are meeting growing interest as SOM contains more carbon (C) than global vegetation and the atmosphere combined. Therefore, SOM is a crucial element of the $\mathrm{C}$ cycle, especially in ecosystems rich in organic matter, such as boreal forests. However, climate change may shift the fate of this SOM from C sink into C source, accelerating global warming. These processes require a better understanding of the involved mechanisms driving both the $\mathrm{C}$ cycle and the interlinked nitrogen $(\mathrm{N})$ cycle. SOM transformations are balanced by a network of interactions between biological, chemical and physical factors. In this review, we discuss the findings of the most recent studies to the current state of knowledge about the main drivers in SOM transformations. We focus on plant-derived secondary metabolites, as their biochemical traits, especially interactions with soil microbial communities, organic $\mathrm{N}$ compounds and enzymes make them potential regulators of SOM decomposition. However, these regulatory abilities of plant-derived compounds are not fully explored.
\end{abstract}

Keywords: enzymatic activity; forest soil; tannins; terpenes

\section{Introduction}

Mechanisms controlling soil organic matter (SOM) formation and decomposition are meeting growing interest as they are critical for soil nutrient cycling and carbon (C) stabilization processes, particularly in ecosystems rich in organic matter, such as boreal forests. These northern forests play a crucial role in the global $C$ cycle due to their high $C$ storage of which significant amounts are fixed in SOM [1]. However, the fate of this $C$ is uncertain in the view of climate change as $C$ in the forest ecosystem might shift from sink to source, thereby accelerating global warming [2]. The decomposition of SOM is regulated by microbial responses to environmental conditions, that is, temperature and precipitation [3], chemical and physical protection of SOM [4], as well as chemical recalcitrance of SOM [5]. Furthermore, plant secondary metabolites (PSM), for example, tannins and terpenes, synthetized to cope with numerous environmental stressors influence these processes via different mechanisms [6,7]. Overall, the mechanisms underlying SOM transformations are not well known yet. As recently underlined, we need better understanding of plant-soil-microbial interactions to improve models of SOM decomposition [8-11]. In this mini-review, we present the current state of the art on SOM transformations in boreal forests with particular focus on the role of tannins and terpenes, dominating PSM. 


\section{SOM Decomposition in Boreal Forests}

Decomposition processes in boreal forests are very slow due to numerous factors influencing the underlying mechanisms, such as specific climatic conditions, with low temperatures and a short growing season. The low $\mathrm{C}$ turnover rates of SOM in these forests might be driven by nitrogen $(\mathrm{N})$ limitation [12-14]. Although boreal forest soils are rich in $\mathrm{N}$, this $\mathrm{N}$ is mostly present in organic forms that are bound to or complexed with other soil compounds, including minerals and organic compounds such as polyphenols and polysaccharides [3,5]. Thus, the crucial step in SOM decomposition is the release of $\mathrm{N}$ from these boundaries, that is, the depolymerization of large $\mathrm{N}$-containing molecules to organic small-molecular-weight compounds $[15,16]$ which can be taken up directly from the soil [17-22]. Knowledge on the fate of $\mathrm{N}$ released from litter into the plant-microbe-soil system is scarce, although litter decomposition has been studied extensively in various biomes [23-27]. This is particularly relevant when the decomposition of root litter is investigated, which has only been done in some studies [28-30], and overall knowledge on the fate of root-litter derived $\mathrm{N}$ is still missing.

Soil organic $C$ derives from plant material [31] and enter the soil with photosynthates and litter passing through soil microbial biomass before transformation into SOM [32]. Soil microorganisms have a dual mode of control over SOM: catabolic, as they decompose organic compounds, or anabolic, as they stabilize $\mathrm{C}$, forming thus more stable SOM [11]. In boreal forests, mycorrhizal fungi (MF) fueled by plant $C$ allocation of recent photosynthates may significantly contribute to the SOM decomposition and mining for $\mathrm{N}$ from soil $[33,34]$. However, competition between MF and saprotrophic fungi might retard SOM decomposition and lead to a build up of SOM [35-37], especially at low fertility soils [38]. Competition between different fungal guilds is not as intensive as previously believed due to vertical separation; saprotrops occupy mainly the litter layer and upper layer of humus, whereas mycorrhizal fungi occur mostly at deeper humus layers [39,40]. Moreover, living roots can significantly accelerate or retard the decomposition of old recalcitrant $C$ in the soil via root exudates (so called "priming effect") [41]. The mechanism of priming has been studied intensively and is reviewed extensively, for example, in Kuzyakov et al. [41]. In contrast to the intensively studied allocation of plant photosynthates belowground fueling soil microbes, the role of other plant-derived compounds shaping microbial communities and affecting SOM decomposition is far from being understood. Among plant-derived compounds, some PSM in particular affect soil processes due to their biochemical traits [7,42-45], that is, by affecting microbial communities (toxicity vs. C source), binding of organic compounds and metal ions, antioxidant activity and modifying enzyme activity [46]; however, research on these effects is scarce.

\section{Effects of PSM on SOM Transformations}

\subsection{Plant Synthesis of PSM and Soil Concentrations}

Plant secondary metabolites are not essential for plant growth, but rather control the interactions of plants with the environment, that is, as defense against pathogens and herbivores [47,48], as allelopathic agents [49], and/or as antioxidants protecting leaves from UV radiation and excess of light [50]. Extractable PSM can comprise even up to $30 \%$ of the dry weight (DW) of plants, especially in forest ecosystems [51], and their concentrations are species-, age-, season- and organ-specific, as well as affected by soil nutrient deficiency, light, temperature, elevated $\mathrm{CO}_{2}$ and drought [52-57]. Plant secondary metabolites consist of two major groups: terpenes and phenolic compounds (including tannins).

Tannins are polyphenols usually separated into hydrolysable tannins (HT) and condensed tannins (CT) (Figure 1). Tannins are the fourth most abundant compounds in vascular plant tissue after cellulose, hemicelluloses and lignin [58]. For example, tannin concentration in pine leaves and roots can reach up to $15-20 \%$ DW $[54,59,60]$. Many studies have shown that high tannin concentration can be found in plants living in conditions of low soil fertility and low $\mathrm{pH}$ [61]. The most diverse group of PSM are terpenes, built up from isoprene units. Terpenes include monoterpenes (having two isoprene units, IU), sesquiterpenes (three IU), diterpenes (four IU), triterpenes (six IU), tetraterpenes (eight, IU), 
and polyterpenes (more than eight IU) [62] (Figure 1). Terpene concentrations in leaves range from 1\% to $2 \%$ DW [62].

A<smiles></smiles>

C<smiles>[R]c1cc([C@@H]2Oc3c([Te])c(O)c([Y])c(O)c3[C@@H](O)[C@@H]2F)cc(O)c1O</smiles>

$\mathrm{R}=\mathrm{H}$; Procyanidin $(\mathrm{PC})$ $\mathrm{R}=\mathrm{OH}$; Prodelphinidin (PD)

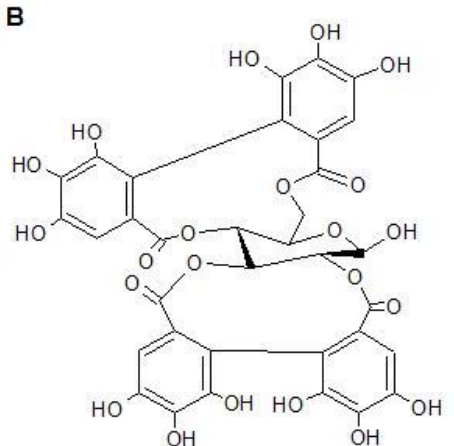

D

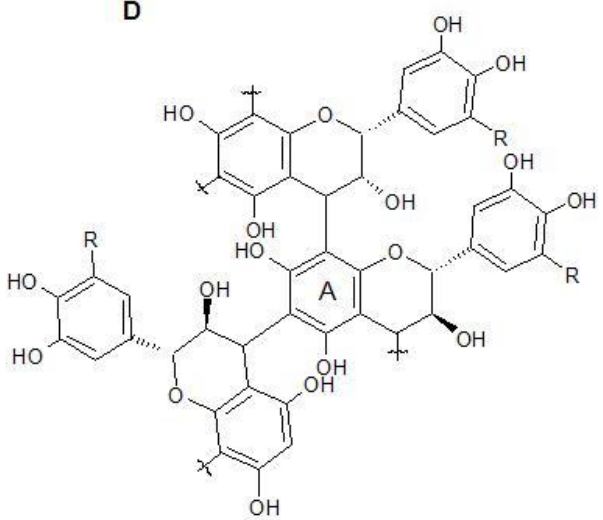

$\mathrm{E}$

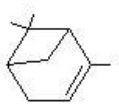

$\mathbf{F}$<smiles>CC(C)C1=CC2=CCC3C(CCCC3(C)C(=O)O)C2CC1</smiles><smiles>CC(C)C1CCC(C)C2CCC3C4CC=C5CC(O)CCC5C4CCC3C12</smiles>

Figure 1. Tannin and terpene chemistry. Hydrolysable tannins are basically divided into gallotannins (A) and ellagitannins (B), which are made up of gallic acid or hexahydroxydiphenic acid esters, respectively, linked to a sugar moiety. Monomers of condensed tannins (CT) can be divided into procyanidins and prodelfinidins $(\mathbf{C})$; Condensed tannins (proanthocyanidins) are polymers of three-ring flavonols joined by $\mathrm{C}-\mathrm{C}$ bonds (D); Terpenes are based on isoprene units; examples of common terpenes: (E) alfa-pinene (monoterpene); (F) abietic acid; (G) beta-sitosterol.

Soil concentrations of PSM depend on litter input and degradation rate regulated by plant species, environmental conditions and microbial community structure but also forest management [54,63-68]. For example, the concentration of terpenes was higher in litter than in the organic layer [63,69]. In the organic layer, concentrations of monoterpenes reached up to $0.2 \mathrm{~g} / \mathrm{kg} \mathrm{SOM}$ with total concentration of sesqui-, di-, and triterpene reaching up to $5 \mathrm{~g} / \mathrm{kg}$ SOM [54]. Hydrolysable tannin concentrations in boreal forest soils are very low [64,67], likely due to generally low HT concentrations in plant litter or fast decomposition rates. On the contrary, CT concentrations are significantly higher, reaching up to a few g per $\mathrm{kg}$ SOM $[63,64,66]$. However, the actual concentrations of tannins in the soil are unknown, because significant amounts of tannins are undetectable due to complexation with proteins and sorption to other compounds in the soil, which strongly decreases the recovery of CTs [46,70]. 


\subsection{Influence of PSM on SOM Transformations}

The effects of PSM on SOM are complex and depend on their chemical structure [43,71]. For example, both tannins and terpenes can affect net $\mathrm{N}$ mineralization and nitrification, soil microbial biomass $\mathrm{C}$ and $\mathrm{N}$ and microbial community structure [6,45,72-75]. The main probable mechanism by which tannins affect soil $\mathrm{N}$ transformations is via binding to proteins. The formation of such tannin-protein complexes depends on the biochemical characteristics of both, the involved protein and tannin as well as the $\mathrm{pH}$ of the soil solution [73,76]. It was suggested by Northup et al. that most of the dissolved organic $\mathrm{N}(\mathrm{DON})$ is associated with protein-tannin complexes, thus conserving litter-derived $\mathrm{N}$ in the forest ecosystem [77]. Furthermore, high levels of tannins present in the litter shift $\mathrm{N}$ cycling from mineral to organic dominated pathways $[72,73,77,78]$. These tannin-protein complexes are recalcitrant mainly due to decreased solubility, thus the formation of complexes stabilize $C$ and build up more stable SOM. Moreover, the addition of tannin-protein complexes to the soil decreased net $\mathrm{N}$ mineralization, respiration, and microbial biomass as compared to protein addition alone $[43,79,80]$. Although tannin-protein complexes seem to be recalcitrant, this source of $\mathrm{N}$ can be accessed by saprotrops, as well as plants via mycorrhiza (both, ericoid and ectomycorrhiza) $[81,82]$. These fungi slowly release $\mathrm{N}$ from complexes using a set of enzymes, including at first step oxidoreductases [81,82]. Recently, Adamczyk et al. [43,44] showed that tannins interact not only with proteins, but also with other organic $\mathrm{N}$ compounds present in the soil, that is, arginine, polyamines, chitin and $\mathrm{N}$ bases. Thus, Northup's theory [73] should be extended to include also other organic $\mathrm{N}$ containing compounds. Overall, the role of other PSM-N complexes other than tannin-protein remain unknown, although tannin-chitin complexes seems to act similarly to tannin-protein complexes [43]. The complexation of chitin by tannins may be a relevant process at ecosystem scale, as roots are tannin-rich and the neighboring ectomycorrhizal symbiont biomass is estimated to range from 100 to $600 \mathrm{~kg} \cdot \mathrm{ha}^{-1}$ [83]. In addition, higher terpenes, that is, abietic acid, colophony (i.e., a mixture of diterpenes) and beta-sitosterol can also precipitate protein. However, the affinity of terpenes to proteins seems to be lower than affinity of tannins [84]. All in all, according to laboratory experiments, additions of PSM to soil affect numerous processes in the forests $\mathrm{N}$ cycle (Figure 2) [30,54]. However, the relationship between PSM and N cycling has not been found as clear under field conditions [54]. Soil is a highly heterogenic environment, with myriads of compounds which can affect interaction between PSM and organic nitrogen. For example, PSM interaction with minerals is potentially important in mineral soils, although knowledge about it is scarce. It has been shown in laboratory study with quartz sand and sand coated with goethite or ferrihydrite that tannins strongly bind to minerals [85]. Protein-tannin complexes and condensed tannins showed lower recovery after addition to more mineral soil than to highly organic soil [70]. Sorption to soil depends on chemical structure of tannins [46]. Interaction of PSM with other soil compounds, as for example with minerals, can contribute to $C$ stabilization, but it can also inactivate tannins and terpenes, affecting their effect on $\mathrm{N}$ cycling.

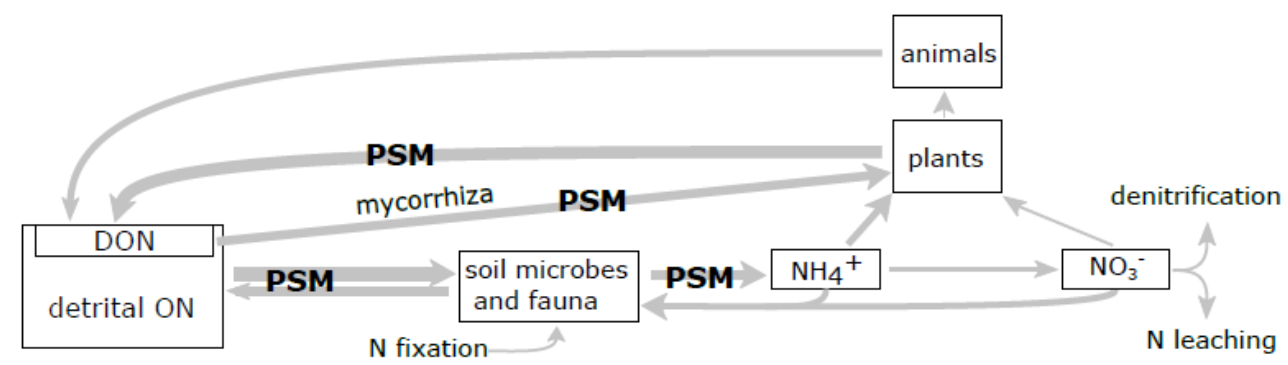

Figure 2. Potential effects of plant secondary metabolites (PSM) on forest N cycling. The model of main fluxes (arrows) and pools (boxes) of $\mathrm{N}$ in terrestrial ecosystems [58,86]. Arrow thickness is proportional to the magnitude of net flux. Processes affected by tannins and terpenes are marked "PSM". DON—dissolved organic nitrogen; ON—organic nitrogen. 


\subsection{Effects of PSM on SOM Degradation via Regulation of Enzymatic Activity}

SOM decomposition is driven by a multiple set of microbial enzymes. Extracellular hydrolytic enzymes convert organic polymers of $\mathrm{C}$ and nutrients to forms available for soil microorganisms and plants. However, the complexation of PSM with organic N compounds (see Section 3.2) decreases SOM degradation rates via the formation of recalcitrant substrates. As PSM interact with proteins, also the effect of PSM on enzymes should be included in models concerning ecosystem functioning. To date, tannins have been viewed as potential enzyme inhibitors [75,87-89], thus potential interactions of tannins with enzymes represent one mechanisms regulating SOM decomposition and explain the low rates of decomposition in tannin-rich ecosystems. However, this effect was not consistent throughout studies, as sometimes no decrease in activity was observed [90]. A recent study conducted with and without soil provided first evidence of the different effects tannins have on enzymatic activity; (1) Additions of low tannin concentrations led to an increase in catalytic activity of enzymes, whereas (2) higher tannin concentrations resulted in a decrease in enzymatic activity [42]. Mechanically, this dual effect of tannins on enzymatic activity is due to changes in the secondary conformation of enzymes after tannin addition [42] (Figure 3). However, even tannin-enzyme complexes exerted some activity [42], which may lead to stabilization of enzymes in the soil. Such stabilization can exert positive effect on soil decomposition processes in the long term. Tannin-bound enzymes may act as a reservoir of enzymatic activity ready to react with changing fluxes of substrate [91]. Monoterpenes have been also proposed as potential enzyme inhibitors, for example, inhibiting ammonia monooxygenase through non-competitive inhibition [92,93]. A recent study in vitro and in soil showed that both, monoterpenes and higher terpenes can inhibit activity of chitinase and beta-glucosidase [94]. Overall, PSM should be seen as potential regulators of SOM decomposition at PSM-rich sites.

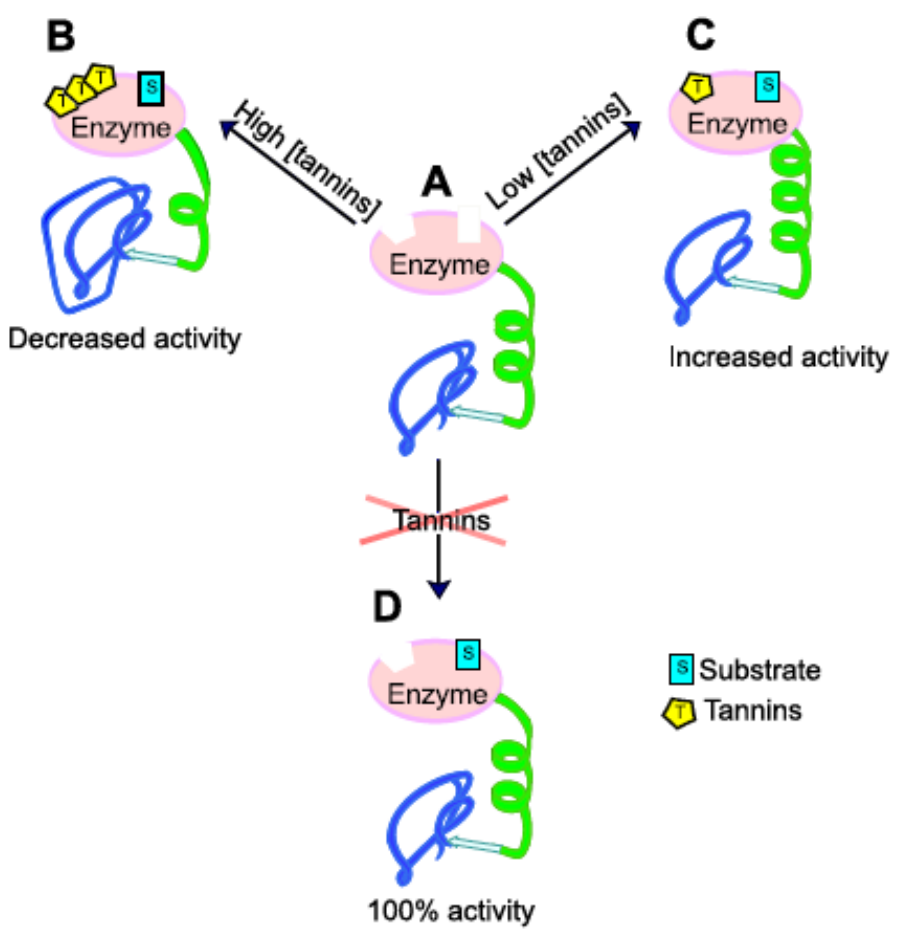

Figure 3. Simplified scheme showing possible effects of tannins on enzymatic activity. (A) enzyme without tannins and substrate; (B) enzyme after reaction with high concentration of tannins; activity is decreased, in secondary structure, more irregular (in blue) and less regular (in green) structures are present; (C) enzyme after reaction with low concentration of tannins, activity is increased; in secondary structure, more regular (in green) and less irregular (in blue) structures are present; (D) enzyme without tannins, $100 \%$ activity. 


\section{Conclusions and Directions of Future Studies}

Future studies on SOM transformations should take into account the complicated plant-soil microbial interactions, and how these are affected by different PSM. Furthermore, as projections for future climate change suggest an increase in temperature, prolonged periods of drought, as well as increased greenhouse gas emissions [95], plant production of PSM is likely to be affected [96]. For example, trees produce tannins that are more likely to form complexes with proteins in response to climatic stress [52]. Furthermore, the concentrations of PSM such as terpenes are increasing with elevated temperature and $\mathrm{CO}_{2}$ levels [53]. Therefore, the effects of PSM on SOM transformations in response to varying climate conditions are likely to change. Moreover, global change may also result in the threat of invasive species, which may provide PSM of different quantity and quality.

Acknowledgments: B.A. is funded by the Finnish Cultural Foundation and J.S. is funded by a Heisenberg Fellowship from the German Research Foundation (DFG).

Author Contributions: B.A. and J.S. wrote the paper with important input from other co-authors.

Conflicts of Interest: The authors declare no conflict of interest.

\section{References}

1. Pan, Y.; Birdsey, R.A.; Fang, J.; Houghton, R.; Kauppi, P.E.; Kurz, W.A.; Phillips, O.L.; Shvidenko, A.; Lewis, S.L.; Canadell, J.G.; et al. A Large and Persistent Carbon Sink in the World's Forests. Science 2011, 333, 988-993. [CrossRef] [PubMed]

2. Crowther, T.W.; Todd-Brown, K.E.O.; Rowe, C.W.; Wieder, W.R.; Carey, J.C.; Machmuller, M.B.; Snoek, B.L.; Fang, S.; Zhou, G.; Allison, S.D.; et al. Quantifying global soil carbon losses in response to warming. Nature 2016, 540, 104-108. [CrossRef] [PubMed]

3. Schmidt, M.W.I.; Torn, M.S.; Abiven, S.; Dittmar, T.; Guggenberger, G.; Janssens, I.A.; Kleber, M.; Kögel-Knabner, I.; Lehmann, J.; Manning, D.A.C.; et al. Persistence of soil organic matter as an ecosystem property. Nature 2011, 478, 49-56. [CrossRef] [PubMed]

4. Mikutta, R.; Kleber, M.; Torn, M.S.; Jahn, R. Stabilization of soil organic matter: Association with minerals or chemical recalcitrance? Biogeochemistry 2006, 77, 25-56. [CrossRef]

5. Korhonen, J.F.J.; Pihlatie, M.; Pumpanen, J.; Aaltonen, H.; Hari, P.; Levula, J.; Kieloaho, A.-J.; Nikinmaa, E.; Vesala, T.; Ilvesniemi, H. Nitrogen balance of a boreal Scots pine forest. Biogeosciences 2013, 10, 1083-1095. [CrossRef]

6. Hättenschwiler, S.; Vitousek, P.M. The role of polyphenols in terrestrial ecosystem nutrient cycling. Trends Ecol. Evol. 2000, 15, 238-243. [CrossRef]

7. Fournier, E.; Loreau, M. Respective roles of recent hedges and forest patch remnants in the maintenance of ground-beetle (Coleoptera: Carabidae) diversity in an agricultural landscape. Landsc. Ecol. 2001, 16, 17-32. [CrossRef]

8. Sulman, B.N.; Phillips, R.P.; Oishi, A.C.; Shevliakova, E.; Pacala, S.W. Microbe-driven turnover offsets mineral-mediated turnover offsets mineral-mediated storage under elevated elevated CO storage of of soil soil carbon carbon under elevated $\mathrm{CO}_{2}$. Nat. Clim. Chang. 2014, 4, 1099-1102. [CrossRef]

9. Hobbie, S.E. Plant species effects on nutrient cycling: Revisiting litter feedbacks. Trends Ecol. Evol. 2015, 30, 357-363. [CrossRef] [PubMed]

10. Lehmann, J.; Kleber, M. Perspective The contentious nature of soil organic matter. Nature 2015, 528, 60-68. [CrossRef] [PubMed]

11. Liang, C.; Schimel, J.P.; Jastrow, J.D. The importance of anabolism in microbial control over soil carbon storage. Nat. Microbiol. 2017, 2, 17105. [CrossRef] [PubMed]

12. Högberg, P.; Näsholm, T.; Franklin, O.; Högberg, M.N. Tamm Review: On the nature of the nitrogen limitation to plant growth in Fennoscandian boreal forests. For. Ecol. Manag. 2017, 403, 161-185. [CrossRef]

13. Schimel, J.; Weintraub, M.N. The implications of exoenzyme activity on microbial carbon and nitrogen limitation in soil: A theoretical model. Soil Biol. Biochem. 2003, 35, 549-563. [CrossRef] 
14. Blaško, R.; Holm Bach, L.; Yarwood, S.A.; Trumbore, S.E.; Högberg, P.; Högberg, M.N. Shifts in soil microbial community structure, nitrogen cycling and the concomitant declining $\mathrm{N}$ availability in ageing primary boreal forest ecosystems. Soil Biol. Biochem. 2015, 91, 200-211. [CrossRef]

15. Kieloaho, A.-J.; Pihlatie, M.; Dominguez Carrasco, M.; Kanerva, S.; Parshintsev, J.; Riekkola, M.-L.; Pumpanen, J.; Heinonsalo, J. Stimulation of soil organic nitrogen pool: The effect of plant and soil organic matter degrading enzymes. Soil Biol. Biochem. 2016, 96, 97-106. [CrossRef]

16. Schimel, J.P.; Bennett, J. Nitrogen mineralization: Challenges of a changing paradigm. Ecology 2004, 85, 591-602. [CrossRef]

17. Melillo, J.M.; Aber, J.D.; Linkins, A.E.; Ricca, A.; Fry, B.; Nadelhoffer, K.J. Carbon and nitrogen dynamics along the decay continuum: Plant litter to soil organic matter. Plant Soil 1989, 115, 189-198. [CrossRef]

18. Näsholm, T.; Ekblad, A.; Nordin, A.; Giesler, R.; Högberg, M.; Högberg, P. Boreal forest plants take up organic nitrogen. Nature 1998, 392, 914-917. [CrossRef]

19. Chapman, S.K.; Langley, J.A.; Hart, S.C.; Koch, G.W. Plants actively control nitrogen cycling: Uncorking the microbial bottleneck. New Phytol. 2006, 169, 27-34. [CrossRef] [PubMed]

20. Inselsbacher, E.; Näsholm, T. The below-ground perspective of forest plants: Soil provides mainly organic nitrogen for plants and mycorrhizal fungi. New Phytol. 2012, 195, 329-334. [CrossRef] [PubMed]

21. Adamczyk, B.; Smolander, A.; Kitunen, V.; Godlewski, M. Proteins as nitrogen source for plants. Plant Signal. Behav. 2010, 5, 817-819. [CrossRef] [PubMed]

22. Näsholm, T.; Kielland, K.; Ganeteg, U. Uptake of organic nitrogen by plants. New Phytol. 2009, 182, 31-48. [CrossRef] [PubMed]

23. McClaugherty, C.A.; Pastor, J.; Aber, J.D.; Melillo, J.M. Forest Litter Decomposition in Relation to Soil Nitrogen Dynamics and Litter Quality. Ecology 1985, 66, 266-275. [CrossRef]

24. Keplin, B.; Hüttl, R.F. Decomposition of root litter in Pinus sylvestris L. and Pinus nigra stands on carboniferous substrates in the Lusatian lignite mining district. Ecol. Eng. 2001, 17, 285-296. [CrossRef]

25. Hobbie, S.E.; Oleksyn, J.; Eissenstat, D.M.; Reich, P.B. Fine root decomposition rates do not mirror those of leaf litter among temperate tree species. Oecologia 2010, 162, 505-513. [CrossRef] [PubMed]

26. Jacob, M.; Viedenz, K.; Polle, A.; Thomas, F.M. Leaf litter decomposition in temperate deciduous forest stands with a decreasing fraction of beech (Fagus sylvatica). Oecologia 2010, 164, 1083-1094. [CrossRef] [PubMed]

27. Coq, S.; Weigel, J.; Butenschoen, O.; Bonal, D.; Hättenschwiler, S. Litter composition rather than plant presence affects decomposition of tropical litter mixtures. Plant Soil 2011, 343, 273-286. [CrossRef]

28. Berg, B. Decomposition of root litter and some factors regulating the process: Long-term root litter decomposition in a scots pine forest. Soil Biol. Biochem. 1984, 16, 609-617. [CrossRef]

29. Berg, B.; Johansson, M.; Meentemeyer, V.; Kratz, W. Decomposition of tree root litter in a climatic transect of coniferous forests in northern Europe: A synthesis. Scand. J. For. Res. 1998, 13, 402-412. [CrossRef]

30. Guo, C.; Dannenmann, M.; Gasche, R.; Zeller, B.; Papen, H.; Polle, A.; Rennenberg, H.; Simon, J. Preferential use of root litter compared to leaf litter by beech seedlings and soil microorganisms. Plant Soil 2013, 368, 519-534. [CrossRef]

31. Kögel-Knabner, I. The macromolecular organic composition of plant and microbial residues as inputs to soil organic matter. Soil Biol. Biochem. 2002, 34, 139-162. [CrossRef]

32. Miltner, A.; Bombach, P.; Schmidt-Brücken, B.; Kästner, M. SOM genesis: Microbial biomass as a significant source. Biogeochemistry 2012, 111, 41-55. [CrossRef]

33. Lindahl, B.D.; de Boer, W.; Finlay, R.D. Disruption of root carbon transport into forest humus stimulates fungal opportunists at the expense of mycorrhizal fungi. ISME J. 2010, 4, 872-881. [CrossRef] [PubMed]

34. Rineau, F.; Roth, D.; Shah, F.; Smits, M.; Johansson, T.; Canbäck, B.; Olsen, P.B.; Persson, P.; Grell, M.N.; Lindquist, E.; et al. The ectomycorrhizal fungus Paxillus involutus converts organic matter in plant litter using a trimmed brown-rot mechanism involving Fenton chemistry. Environ. Microbiol. 2012, 14, 1477-1487. [CrossRef] [PubMed]

35. Gadgil, R.L.; Gadgil, P.D. Mycorrhiza and Litter Decomposition. Nature 1971, 233, 133. [CrossRef] [PubMed]

36. Averill, C.; Hawkes, C.V. Ectomycorrhizal fungi slow soil carbon cycling. Ecol. Lett. 2016, 19, 937-947. [CrossRef] [PubMed]

37. Fernandez, C.W.; Kennedy, P.G. Revisiting the "Gadgil effect": Do interguild fungal interactions control carbon cycling in forest soils? New Phytol. 2016, 209, 1382-1394. [CrossRef] [PubMed] 
38. Kyaschenko, J.; Clemmensen, K.E.; Hagenbo, A.; Karltun, E.; Lindahl, B.D. Shift in fungal communities and associated enzyme activities along an age gradient of managed Pinus sylvestris stands. ISME J. 2017, 11, 863-874. [CrossRef] [PubMed]

39. Lindahl, B.D.; Ihrmark, K.; Boberg, J.; Trumbore, S.E.; Högberg, P.; Stenlid, J.; Finlay, R.D. Spatial separation of litter decomposition and mycorrhizal nitrogen uptake in a boreal forest. New Phytol. 2007, 173, 611-620. [CrossRef] [PubMed]

40. Santalahti, M.; Sun, H.; Jumpponen, A.; Pennanen, T.; Heinonsalo, J. Vertical and seasonal dynamics of fungal communities in boreal Scots pine forest soil. FEMS Microbiol. Ecol. 2016, 92. [CrossRef] [PubMed]

41. Kuzyakov, Y.; Friedel, J.; Stahr, K. Review of mechanisms and quantification of priming effects. Soil Biol. Biochem. 2000, 32, 1485-1498. [CrossRef]

42. Adamczyk, B.; Karonen, M.; Adamczyk, S.; Engström, M.T.; Laakso, T.; Saranpää, P.; Kitunen, V.; Smolander, A.; Simon, J. Tannins can slow-down but also speed-up soil enzymatic activity in boreal forest. Soil Biol. Biochem. 2017, 107, 60-67. [CrossRef]

43. Adamczyk, B.; Kitunen, V.; Smolander, A. Response of soil C and N transformations to condensed tannins and different organic N-condensed tannin complexes. Appl. Soil Ecol. 2013, 64, 163-170. [CrossRef]

44. Adamczyk, B.; Adamczyk, S.; Smolander, A.; Kitunen, V. Tannic acid and Norway spruce condensed tannins can precipitate various organic nitrogen compounds. Soil Biol. Biochem. 2011, 43, 628-637. [CrossRef]

45. Adamczyk, S.; Adamczyk, B.; Kitunen, V.; Smolander, A. Influence of diterpenes (colophony and abietic acid) and a triterpene (beta-sitosterol) on net $\mathrm{N}$ mineralization, net nitrification, soil respiration, and microbial biomass in birch soil. Biol. Fertil. Soils 2011, 47, 715-720. [CrossRef]

46. Schmidt, M.A.; Halvorson, J.J.; Gonzalez, J.M.; Hagerman, A.E. Kinetics and binding capacity of six soils for structurally defined hydrolyzable and condensed tannins and related phenols. J. Soils Sediments 2012, 12, 366-375. [CrossRef]

47. Harbone, J.B. Role of Phenolic Secondary Metaboltes in Plants and their degradation in Nature. In Driven by Nature. Plant Litter Quality and Decomposition; CAB International: Wallingford, UK, 1997; pp. 67-74, ISBN 0851991459.

48. Agrawal, A.A.; Weber, M.G. On the study of plant defence and herbivory using comparative approaches: How important are secondary plant compounds. Ecol. Lett. 2015, 18, 985-991. [CrossRef] [PubMed]

49. Croteau, R.; Kutchan, T.M.; Lewis, N.G. Natural products Secondary Metabolites. In Biochemistry Molecular Biology of Plants; Wiley: Hoboken, NJ, USA, 2000; Volume 7, pp. 1250-1318, ISBN 0943088399.

50. Close, D.C.; McArthur, C. Rethinking the role of many plant phenolics-Protection from photodamage not herbivores? Oikos 2002, 99, 166-172. [CrossRef]

51. Horwath, W. Chapter 12-Carbon Cycling: The Dynamics and Formation of Organic Matter. In Soil Microbiology, Ecology and Biochemistry, 4th ed.; Paul, E.A., Ed.; Academic Press: Boston, MA, USA, 2015; pp. 339-382, ISBN 978-0-12-415955-6.

52. Tharayil, N.; Suseela, V.; Triebwasser, D.J.; Preston, C.M.; Gerard, P.D.; Dukes, J.S. Changes in the structural composition and reactivity of Acer rubrum leaf litter tannins exposed to warming and altered precipitation: Climatic stress-induced tannins are more reactive. New Phytol. 2011, 191, 132-145. [CrossRef] [PubMed]

53. Väisänen, M.; Martz, F.; Kaarlejärvi, E.; Julkunen-Tiitto, R.; Stark, S. Phenolic responses of mountain crowberry (Empetrum nigrum ssp. hermaphroditum) to global climate change are compound specific and depend on grazing by reindeer (Rangifer tarandus). J. Chem. Ecol. 2013, 39, 1390-1399. [CrossRef] [PubMed]

54. Smolander, A.; Kanerva, S.; Adamczyk, B.; Kitunen, V. Nitrogen transformations in boreal forest soils-Does composition of plant secondary compounds give any explanations? Plant Soil 2012, 350, 1-26. [CrossRef]

55. Barton, K.E.; Koricheva, J. The Ontogeny of Plant Defense and Herbivory: Characterizing General Patterns Using Meta-Analysis. Am. Nat. 2010, 175, 481-493. [CrossRef] [PubMed]

56. Boege, K.; Marquis, R.J. Facing herbivory as you grow up: The ontogeny of resistance in plants. Trends Ecol. Evol. 2017, 20, 441-448. [CrossRef] [PubMed]

57. Wam, H.K.; Stolter, C.; Nybakken, L. Compositional Changes in Foliage Phenolics with Plant Age, a Natural Experiment in Boreal Forests. J. Chem. Ecol. 2017, 43, 920-928. [CrossRef] [PubMed]

58. Kraus, T.E.C.; Dahlgren, R.A.; Zasoski, R.J. Tannins in nutrient dynamics of forest ecosystems-A review. Plant Soil 2003, 256, 41-66. [CrossRef]

59. Xia, M.; Talhelm, A.F.; Pregitzer, K.S. Fine roots are the dominant source of recalcitrant plant litter in sugar maple-dominated northern hardwood forests. New Phytol. 2015, 208, 715-726. [CrossRef] [PubMed] 
60. Adamczyk, B.; Ahvenainen, A.; Sietiö, O.-M.; Kanerva, S.; Kieloaho, A.-J.; Smolander, A.; Kitunen, V.; Saranpää, P.; Laakso, T.; Strakova, P.; et al. The contribution of ericoid plants to soil nitrogen chemistry and and organic matter composition in boreal forest soil. Soil Biol. Biochem. 2016, 103, 394-404. [CrossRef]

61. Northup, R.R.; Dahlgren, R.A.; McColl, J.G. Polyphenols as regulators of plant-litter-soil interactions in Northern California's pygmy forest: A positive feedback? Biogeochemistry 1998, 42, 189-220. [CrossRef]

62. Langenheim, J.H. Heigher plant terpenooids: A phytocentric overview of their ecological roles. J. Chem. Ecol. 1994, 20, 1223-1280. [CrossRef] [PubMed]

63. Kanerva, S.; Smolander, A. How do coniferous needle tannins influence $\mathrm{C}$ and $\mathrm{N}$ transformations in birch humus layer? Eur. J. Soil Biol. 2008, 44, 1-9. [CrossRef]

64. Adamczyk, B.; Kitunen, V.; Smolander, A. Polyphenol oxidase, tannase and proteolytic activity in relation to tannin concentration in the soil organic horizon under silver birch and Norway spruce. Soil Biol. Biochem. 2009, 41, 2085-2093. [CrossRef]

65. Smolander, A.; Kitunen, V.; Tamminen, P.; Kukkola, M. Removal of logging residue in Norway spruce thinning stands: Long-term changes in organic layer properties. Soil Biol. Biochem. 2010, 42, 1222-1228. [CrossRef]

66. Smolander, A.; Loponen, J.; Suominen, K.; Kitunen, V. Organic matter characteristics and C and N transformations in the humus layer under two tree species, Betula pendula and Picea abies. Soil Biol. Biochem. 2005, 37, 1309-1318. [CrossRef]

67. Adamczyk, B.; Kitunen, V.; Smolander, A. Protein precipitation by tannins in soil organic horizon and vegetation in relation to tree species. Biol. Fertil. Soils 2008, 45. [CrossRef]

68. Adamczyk, S.; Kitunen, V.; Lindroos, A.-J.; Adamczyk, B.; Smolander, A. Soil carbon and nitrogen cycling processes and composition of terpenes five years after clear-cutting a Norway spruce stand: Effects of logging residue. For. Ecol. Manag. 2016, 381, 318-326. [CrossRef]

69. Stark, S.; Hilli, S.; Willför, S.; Smeds, A.I.; Reunanen, M.; Penttinen, M.; Hautajärvi, R. Composition of lipophilic compounds and carbohydrates in the accumulated plant litter and soil organic matter in boreal forests. Eur. J. Soil Sci. 2012, 63, 65-74. [CrossRef]

70. Adamczyk, B.; Kiikkilä, O.; Kitunen, V.; Smolander, A. Can we measure condensed tannins from tannin-protein complexes?-A case study with acid-butanol assay in boreal forest soil organic layer. Eur. J. Soil Biol. 2014, 64, 40-45. [CrossRef]

71. Preston, C.M.; Bhatti, J.S.; Flanagan, L.B.; Norris, C. Stocks, chemistry, and sensitivity to climate change of dead organic matter along the Canadian boreal forest transect case study. Clim. Chang. 2006, 74, $233-251$. [CrossRef]

72. Schimel, J.P.; Van Cleve, K.; Cates, R.G.; Clausen, T.P.; Reichardt, P.B. Effects of balsam poplar (Populus balsamifera) tannins and low molecular weight phenolics on microbial activity in taiga floodplain soil: Implications for changes in N cycling during succession. Can. J. Bot. 1996, 74, 84-90. [CrossRef]

73. Fierer, N.; Schimel, J.P.; Cates, R.G.; Zou, J. Influence of balsam poplar tannin fractions on carbon and nitrogen dynamics in Alaskan taiga floodplain soils. Soil Biol. Biochem. 2001, 33, 1827-1839. [CrossRef]

74. Asensio, D.; Rapparini, F.; Peñuelas, J. AM fungi root colonization increases the production of essential isoprenoids vs. nonessential isoprenoids especially under drought stress conditions or after jasmonic acid application. Phytochemistry 2012, 77, 149-161. [CrossRef] [PubMed]

75. Bardon, C.; Piola, F.; Bellvert, F.; Haichar, F.Z.; Comte, G.; Meiffren, G.; Pommier, T.; Puijalon, S.; Tsafack, N.; Poly, F. Evidence for biological denitrification inhibition (BDI) by plant secondary metabolites Evidence for biological denitrification inhibition (BDI) by plant secondary metabolites. New Phytol. 2014, 204, 620-630. [CrossRef] [PubMed]

76. Hagerman, A.E.; Butler, L.G. The specificity of proanthocyanidin-protein interactions. J. Biol. Chem. 1981, 256, 4494-4497. [PubMed]

77. Northup, R.R.; Yu, Z.; Dahlgren, R.A.; Vogt, K.A. Polyphenol control of nitrogen release from pine litter. Nature 1995, 377, 227-229. [CrossRef]

78. Schimel, J.P.; Cates, R.G.; Ruess, R. The role of balsam poplar secondary chemicals in controlling soil nutrient dynamics through succession in the Alaskan taiga. Biogeochemistry 1998, 42, 221-234. [CrossRef]

79. Joanisse, G.D.; Bradley, R.L.; Preston, C.M.; Munson, A.D. Soil enzyme inhibition by condensed litter tannins may drive ecosystem structure and processes: The case of Kalmia angustifolia. New Phytol. 2007, 175, 535-546. [CrossRef] [PubMed] 
80. Mutabaruka, R.; Hairiah, K.; Cadisch, G. Microbial degradation of hydrolysable and condensed tannin polyphenol-protein complexes in soils from different land-use histories. Soil Biol. Biochem. 2007, 39, 1479-1492. [CrossRef]

81. Bending, G.D. Litter decomposition, ectomycorrhizal roots and the "Gadgil" effect. New Phytol. 2003, 158, 228-229. [CrossRef]

82. Bennett, J.N.; Prescott, C.E. Organic and inorganic nitrogen nutrition of western red cedar, western hemlock and salal in mineral N-limited cedar-hemlock forests. Oecologia 2004, 141, 468-476. [CrossRef] [PubMed]

83. Wallander, H.; Nilsson, L.O.; Hagerberg, D.; Baath, E. Estimation of the biomass and seasonal growth of external mycelium of ectomycorrhizal fungi in the field. New Phytol. 2001, 151, 753-760. [CrossRef]

84. Adamczyk, S.; Kiikkilä, O.; Kitunen, V.; Smolander, A. Potential response of soil processes to diterpenes, triterpenes and tannins: Nitrification, growth of microorganisms and precipitation of proteins. Appl. Soil Ecol. 2013, 67, 47-52. [CrossRef]

85. Kaal, J.; Nierop, K.G.J.; Verstraten, J.M. Retention of tannic acid and condensed tannin by Fe-oxide-coated quartz sand. J. Colloid Interface Sci. 2005, 287, 72-79. [CrossRef] [PubMed]

86. Chapin, F.S., III. New cog in the nitrogen cycle. Nature 1995, 377, 199-200. [CrossRef]

87. Adamczyk, B.; Salminen, J.P.; Smolander, A.; Kitunen, V. Precipitation of proteins by tannins: Effects of concentration, protein/tannin ratio and pH. Int. J. Food Sci. Technol. 2012, 47, 875-878. [CrossRef]

88. Goldstein, J.L.; Swain, T. Changes in tannins in ripening fruits. Phytochemistry 1963, 2, 371-383. [CrossRef]

89. Hagerman, A.E. Fifty Years of Polyphenol-Protein Complexes. In Recent Advances in Polyphenol Research; WILEY: Hoboken, NJ, USA, 2012; Volume 3, pp. 71-97, ISBN 9781444337464.

90. Juntheikki, M.-R.; Julkunen-Tiitto, R. Inhibition of $\beta$-glucosidase and esterase by tannins from Betula, Salix, and Pinus species. J. Chem. Ecol. 2000, 26, 1151-1165. [CrossRef]

91. Burns, R.G.; DeForest, J.L.; Marxsen, J.; Sinsabaugh, R.L.; Stromberger, M.E.; Wallenstein, M.D.; Weintraub, M.N.; Zoppini, A. Soil enzymes in a changing environment: Current knowledge and future directions. Soil Biol. Biochem. 2013, 58, 216-234. [CrossRef]

92. White, C.S. Monoterpenes: Their effects on ecosystem nutrient cycling. J. Chem. Ecol. 1994, 20, 1381-1406. [CrossRef] [PubMed]

93. Ward, B.B.; Courtney, K.J.; Langenheim, J.H. Inhibition of nitrosomonas europaea by monoterpenes from coastal redwood (Sequoia sempervirens) in whole-cell studies. J. Chem. Ecol. 1997, 23, 2583-2598. [CrossRef]

94. Adamczyk, S.; Adamczyk, B.; Kitunen, V.; Smolander, A. Monoterpenes and higher terpenes may inhibit enzyme activities in boreal forest soil. Soil Biol. Biochem. 2015, 87, 59-66. [CrossRef]

95. Intergovernmental Panel on Climate Change (IPCC). Climate Change 2013: The Physical Science Basis. Summary for Policymakers; IPCC: Geneve, Switzerland, 2013; pp. 1-29.

96. Stark, S.; Väisänen, M.; Ylänne, H.; Julkunen-Tiitto, R.; Martz, F. Decreased phenolic defence in dwarf birch (Betula nana) after warming in subarctic tundra. Polar Biol. 2015, 38, 1993-2005. [CrossRef] 